\title{
Effects of energy restriction and fish oil supplementation on renal guanidino levels and antioxidant defences in aged lupus-prone $B / W$ mice
}

\author{
You Jung $\mathrm{Kim}^{1}$, Takako Yokozawa ${ }^{2}$ and Hae Young Chung ${ }^{3 *}$ \\ ${ }^{1}$ Department of Cosmetology, Pusan Women's College, Pusanjin-Gu, Pusan, Korea \\ ${ }^{2}$ Institute of Natural Medicine, Toyama Medical and Pharmaceutical University, 2630 Sugitani, Toyama 930-0194, Japan \\ ${ }^{3}$ Department of Pharmacy, Longevity Life Science and Technology Institutes, Aging Tissue Bank, Pusan National University, \\ Kumjeong-Gu, Pusan, Korea
}

(Received 7 June 2004 - Revised 21 January 2005 - Accepted 23 January 2005)

\begin{abstract}
Energy restriction (ER) and dietary fish oil (FO) are known to reduce the severity of glomerulonephritis and increase the lifespan of lupus-prone $(\mathrm{NZB} \times \mathrm{NZW}) \mathrm{F}_{1}(\mathrm{~B} / \mathrm{W})$ mice. In the present study, mice were fed either ad libitum or energy-restricted (a $40 \%$ lower energy intake than the diet ad libitum), semi-purified diets containing $5 \%$ maize oil or $5 \%$ fish oil supplementation. To estimate the renal damage associated with oxidative stress, the total amounts of reactive oxygen species (ROS), cyclooxygenase-derived ROS and levels of guanidino compounds were measured. Additionally, we assessed the putative action of ER and FO on several key antioxidant enzymes measured in the kidney post-mitochondrial fraction. Results showed that the age-related increase in creatinine level was significantly reduced by ER and FO in old mice. In contrast, arginine and guanidino acetic acid levels showed a decrease with age but were increased by ER and FO. The GSH:GSSG ratio showed a significant decrease with age, whereas ER and FO feeding prevented the decrease. The age-related decrease in antioxidant scavenging superoxide dismutase, catalase and glutathione peroxidase activities were all reversed by ER and FO. The moderately decreased glutathione reductase and glutathione-S-transferase activities with age were significantly increased by ER and FO. Furthermore, the increased total ROS and cyclooxygenase-derived ROS levels were effectively reduced by ER and FO. In conclusion, our data strongly indicate that ER and FO maintain antioxidant status and GSH:GSSG ratio, thereby protecting against renal deterioration from oxidative insults during ageing.
\end{abstract}

Energy restriction: Dietary fish oil: GSH:GSSG ratio: Guanidino compounds: Antioxidant enzymes: Oxidative stress

Autoimmune disease-prone $(\mathrm{NZB} \times \mathrm{NZW}) \mathrm{F} 1(\mathrm{~B} / \mathrm{W})$ mice spontaneously develop immune complex-mediated glomerulonephritis that resembles human systemic lupus erythematosus (Kubo et al. 1984). In these mice, lupus nephritis begins young and results in death from renal failure (Morrow et al. 1985). The female mice of this strain usually die from renal insufficiency between 8 and 9 months of age, and male mice die between 10 and 22 months of age.

Renal insufficiency is often shown to be ameliorated by nutritional intervention (Kono \& Theofilopoulos, 2000); for example, energy restriction (ER) and dietary fish oil (FO), both of which show anti-inflammatory efficacy, can reduce disease severity in the lupus nephritis experimental animal model (Judex et al. 2000; Muthukumar et al. 2000). In addition, ER and FO are shown to ameliorate autoimmune disease, delay age-related disease and increase lifespan (Jolly et al. 2001a,b).

In lupus nephritis-prone B/W mice, guanidino compound (GUC) has been used as a useful renal marker when monitoring the effect of interventions (Levillain et al. 2001). One of the major factors involved in renal abnormalities is the accumulation of GUC that are generated from amino acid and protein metabolism (Guarnieri et al. 2003). Changes in GUC are considered to be an indicator of uraemia, and they have been suggested as major uraemic toxins because the severity of renal disease is closely related to the increased GUC level. The metabolic pathway of GUC in the uraemic condition produces guanidino acetic acid and guanidino butyric acid (Vanholder, 2003). It has been reported that the cause of renal insufficiency by the accumulation of GUC is related to oxidative stress, which is caused by increased oxidants, including reactive oxygen species (ROS) (Nohara et al. 2002) and/or a deficient antioxidant defence system. However, the precise mechanistic relation between GUC levels and oxidative stress is currently not well delineated.

Oxidative stress due to redox imbalance can be modulated by many factors, including the suppression of ROS production and enhanced antioxidative defences. Increased pro-inflammatory prostaglandin biosynthesis with age, which is catalysed by cyclooxygenase, is a substantial source of ROS production during ageing (Chung et al. 2002). For endogenous defences, superoxide dismutase detoxifies superoxide radicals (Pey et al. 2003), catalase decomposes $\mathrm{H}_{2} \mathrm{O}_{2}$, and glutathione peroxidase catalyses the reduction of hydroperoxides, which protect tissues 
from oxidative damage. In addition, glutathione reductase and glutathione-S-transferase protect cellular components from free radical oxidation (Sailaja et al. 2003). At present, the status of these antioxidative enzymes has not been fully characterized in $(\mathrm{NZB} \times \mathrm{NZW}) \mathrm{F}_{1}(\mathrm{~B} / \mathrm{W})$ mice, and their protective role in the age-related renal dysfunction is not well defined.

A compromised antioxidant defence system in the pathogenesis of inflammatory diseases has been blamed for the acceleration of the ageing process (Chung et al. 2001) and the induction of several autoimmune diseases (Cardinali et al. 2004). However, the beneficial role of increasing antioxidant defences by dietary means in autoimmune disease needs further investigation. Thus, in this present work, we examined the oxidative status of the experimental mice by assessing the putative effects of ER and FO on total ROS and cyclooxygenase-derived ROS, renal GUC levels and renal antioxidant enzyme activities. Investigation into GUC levels and oxidative stress in $\mathrm{B} / \mathrm{W}$ mice during ageing may uncover clues to the dietary effects in the amelioration of autoimmune systemic lupus erythematosus.

\section{Materials and methods}

\section{Experimental animals and dietary groups}

$(\mathrm{NZB} \times \mathrm{NZW}) \mathrm{F}_{1}$ weaning female mice (4 weeks old) obtained from the Jackson Laboratories (Bar Harbor, ME, USA) were fed a nutritionally adequate semi-purified diet containing either maize oil (Harlan Bioproducts, Indianapolis, IN, USA), which has higher levels of oleic acid $(18: 81 n$-9), or FO (deodorized menhaden oil) with a high content of palmitic acid (168:80), EPA (208: 85n3 ) and DHA (228:86n-3). Mice were either fed ad libitum or given an ER diet (40\% fewer energy than feeding ad libitum). Agedmatched groups of mice (young, 3-4 months; old, 8-10 months) were divided into eight groups: $\mathrm{CO} / \mathrm{AL} / \mathrm{Y}$ (maize oil-fed, ad libitum, young mice), $\mathrm{CO} / \mathrm{AL} / \mathrm{O}$ (maize oil-fed, ad libitum, old mice), $\mathrm{CO} /$ ER/Y (maize oil-fed, energy-restricted, young mice), CO/ER/O (maize oil-fed, energy-restricted, old mice), FO/AL/Y (fish oilfed, ad libitum, young mice), FO/AL/O (fish oil-fed, ad libitum, old mice), FO/ER/Y (fish oil-fed, energy-restricted, young mice) and FO/ER/O (fish oil-fed, energy-restricted, old mice). Restriction of food intake (i.e. energy-restriction) was implemented from 2 months old until the mice were killed.

The composition of the semi-purified diet was as follows: casein, $20 \%$; maize oil or FO, $5 \%$; starch, $32 \%$; dextrose, $33 \%$; fibre, 4-5\%; DL-methionine, $0-3 \%$; choline chloride, $0-$ $2 \%$; salt mixture (AIN mineral mixture 76; ICN, Cleveland, OH, USA), 3-5\%; vitamin mix (Vitamin diet fortification; ICN), 1-5\%. As compensation for decreased food intake, the ER diet was supplemented with twice the vitamin and mineral mixture. This provided an 'isonutrient' diet for the ER animals, which consumed 11-12 kcal compared with the animals fed ad libitum, which consumed $18-20 \mathrm{kcal}$. The initiation and maintenance of food and energy intake of these mice is described elsewhere in detail (Reddy et al. 2002). Diets were prepared weekly, and a known amount of fresh food was provided daily. Precautions were taken to avoid lipid peroxidation. The mice were maintained in plastic cages, and a $12 \mathrm{~h}$ light/dark cycle was followed. Animals were killed by decapitation at 3-4 months of age (for young) and 8-10 months of age (for old); kidney was collected aseptically, snap-frozen in liquid $\mathrm{N}_{2}$, and stored at $-80^{\circ} \mathrm{C}$.

\section{Preparation of kidney post-mitochondrial fraction}

The kidney was rinsed in ice-cold physiological saline and minced with scissors. A $10 \%$ homogenate of kidney was prepared in $0.15 \mathrm{M}-\mathrm{KCl}$ buffer $(\mathrm{pH} \mathrm{7.4)}$ ) and centrifuged at $12000 \mathrm{~g}$ for $10 \mathrm{~min}$. The pellet was discarded, and the supernatant labelled as post-mitochondrial fraction was used for the biochemical analyses including antioxidant enzymes and GSH.

\section{Measurement of creatinine, arginine and guanidino acetic acid levels}

The kidney tissue samples were deproteinized by the addition of TCA. After centrifugation at $3000 \mathrm{rpm}$ for $15 \mathrm{~min}$, the supernatant was filtered through a $0.2 \mu \mathrm{m}$ membrane filter, and the filtrate was analysed. Arginine, creatinine and guanidino acetic acid levels were measured using a spectroscopic liquid chromatograph employing a step-gradient system according to the method of Higashidate et al. (1984). A fluorescence spectrometer, model FP-210 (Japan Spectroscopic Co., Tokyo, Japan), was used (excitation $365 \mathrm{~nm}$, emission $495 \mathrm{~nm}$ ) to measure creatinine, arginine and guanidino acetic acid.

\section{Determination of oxidative stress markers GSH and GSSG}

Assays for GSH and GSSG were carried out by the method of Pandey and Katiyar (1996). Briefly, $25 \%$ meta-phosphoric acidadded post-mitochondrial fraction was centrifuged at $1200 \mathrm{rpm}$ for $10 \mathrm{~min}$, and the supernatants were taken for assay. To assay for GSH, 1 mM-EDTA-50 mM-phosphate buffer ( $\mathrm{pH} 7.4$ ) was added to the supernatant followed by $o$-phthalaldehyde. After $20 \mathrm{~min}$ at room temperature, the fluorescence was measured at an excitation wavelength of $460 \mathrm{~nm}$. GSSG was assayed after pre-incubation with $\mathrm{N}$-ethylmaleimide for $20 \mathrm{~min}$, and $0.1 \mathrm{M}$ $\mathrm{NaOH}$ was substituted for $1 \mathrm{~mm}$-phosphate buffer.

\section{Assay for antioxidant enzymes}

Superoxide dismutase activity. Superoxide dismutase activity was measured using the xanthine oxidase-cytochrome $\mathrm{c}$ system as described by McCord and Fridovich (1988), and aliquots of post-mitochondrial fraction $(7-8 \mathrm{mg}$ protein/ml) were used for assay. Briefly, the reaction mixture consisted of $2.4 \mathrm{ml} 50 \mathrm{mM}-$ potassium phosphate buffer ( $\mathrm{pH} 7 \cdot 2$ ) containing $0.1 \mathrm{mm-EDTA}$, $0.3 \mathrm{ml} \quad 0.1 \mathrm{~mm}$-ferricytochrome c, $0.2 \mathrm{ml} 1 \%$ deoxycholate, $0.1 \mathrm{~mm}-1.5 \mathrm{~mm}$ potassium cyanide, $0.3 \mathrm{ml} 0.5 \mathrm{~mm}$-xanthine and $20 \mu \mathrm{l}$ appropriately diluted xanthine oxidase to produce a rate of reduction of ferricytochrome $\mathrm{c}$ at $550 \mathrm{~nm}$ of 0.025 absorbance unit/min at $25^{\circ} \mathrm{C}$. One unit of superoxide dismutase is defined as the amount of superoxide dismutase required to inhibit the rate of cytochrome c reduction by $50 \%$.

Catalase activity. Catalase activity was determined using the method of Aebi (1984), and post-mitochondrial fraction was used. The reaction mixture $(3 \mathrm{ml})$ consisted of $50 \mathrm{~mm}$-phosphate buffer (pH 7.0), $1 \mathrm{ml} 30 \mathrm{~mm}-\mathrm{H}_{2} \mathrm{O}_{2}$ in phosphate buffer, and catalase activity was expressed as $\mu \mathrm{mol} \mathrm{H}_{2} \mathrm{O}_{2}$ reduced/min per mg protein.

Glutathione peroxidase and glutathione reductase activity. Glutathione peroxidase and glutathione reductase activity were measured by monitoring the oxidation of NADPH at $340 \mathrm{~nm}$ according to the method of Tappel et al. (1989). Post-mitochondrial 
fraction was used. $\mathrm{H}_{2} \mathrm{O}_{2}$ was used to determine glutathione peroxidase activity.

Glutathione-S-transferase activity. Glutathione-S-transferase activity was assayed by the method of Habig et al. (1974). Aliquots of post-mitochondrial fraction $(7-8 \mathrm{mg}$ protein $/ \mathrm{ml})$ were used for the assay. The conjugate of GSH with 1-chloro-2,5-dinitrobenzene was measured at $340 \mathrm{~nm}$ spectrophotometrically.

\section{Quantitation of reactive oxygen species}

Total ROS generation was assessed by following the method of Ali et al. (1992). Briefly, $25 \mathrm{~mm} \mathrm{2} 2^{\prime}, 7^{\prime}$-dichloro fluorescein diacetate was added to aliquots of post-mitochondrial fraction (7-8 $\mathrm{mg}$ protein $/ \mathrm{ml}$ ). After $30 \mathrm{~min}$, changes in fluorescence were measured at an excitation wavelength of $486 \mathrm{~nm}$ and an emission wavelength of $530 \mathrm{~nm}$ for $30 \mathrm{~min}$.

\section{Measurement of cyclooxgyenase-derived reactive oxygen species}

Cyclooxygenase-derived ROS were estimated utilizing the $2^{\prime}, 7^{\prime}$ dichloro fluorescein diacetate method in the presence of cyclooxygenase inhibitor. Briefly, aliquots of post-mitochondrial fraction (7-8 $\mathrm{mg}$ protein/ml) were preincubated with $1 \mathrm{~mm}$-indomethacin for $10 \mathrm{~min}$, and changes in fluorescence were monitored at $486 \mathrm{~nm}$ (excitation) and $530 \mathrm{~nm}$ (emission). The difference between the condition with and without indomethacin was taken as the amount of cyclooxgyenase-derived ROS generation.

\section{Protein assay}

The concentration of protein was measured by Lowry's method using bovine serum albumin as a standard (Lowry et al. 1951).

\section{Statistical analysis}

All results are expressed as means with their standard errors and analysed statistically using a repeated measures ANOVA procedure. Differences between groups at the various ages were tested using a Student's $t$ test and Duncan multiple range tests for multiple comparisons.

\section{Results}

\section{Effects of age and dietary intervention on creatinine level}

The effects of ER and FO on creatinine level are shown in Fig. 1(A). Renal creatinine levels showed a remarkable increase $(186 \%)$ with age in the group fed maize oil ad libitum, but in the $\mathrm{CO} / \mathrm{ER} / \mathrm{O}$ group, creatinine levels were significantly decreased $(65 \%)$ compared with the CO/AL/O group; in the $\mathrm{FO} / \mathrm{AL} / \mathrm{O}$ and $\mathrm{FO} / \mathrm{ER} / \mathrm{O}$ groups, the levels decreased by $75 \%$ and $72 \%$, respectively, compared with those in the CO/AL/O group. Thus, the dietary intervention suppressed creatinine increases in old mice, and the beneficial effects were detected even in the young ER and FO groups.

\section{Changes in arginine levels}

The changes in arginine level are shown in Fig. 1(B). The renal arginine level showed a $26 \%$ decrease in the old mice fed maize oil ad libitum; however, in the FO/ER/O group, the arginine level increased by $52 \%$. In addition, the suppressed level of arginine with age was effectively increased by ER and FO in both young and old mice.

\section{Effects of age and diet on guanidino acetic acid level}

As shown in Fig. 1(C), renal guanidino acetic acid was reduced substantially with age in the maize oil-fed groups, whereas this decrease was blunted by ER and FO. In contrast, in the CO/ER/ $\mathrm{O}$ group, renal guanidino acetic acid levels markedly increased compared with the $\mathrm{CO} / \mathrm{AL} / \mathrm{O}$ group. In addition, the increases in guanidino acetic acid levels in the FO/AL/O and FO/ER/O groups were also substantial. Thus, although renal guanidino acetic acid levels were shown to decrease with age, ER and FO lessened this decrease in old mice. In young mice, however, there was only a slight effect of ER or FO on the reduction of guanidino acetic acid.

\section{Changes in GSH, GSSG and GSH:GSSG ratio}

GSH and GSSG levels and their ratio are shown in Fig. 2(A), Fig. 2(B) and Fig. 2(C), respectively. GSH levels showed a significant decrease with age; this was, however, markedly increased in the $\mathrm{CO} / \mathrm{ER} / \mathrm{O}, \mathrm{FO} / \mathrm{AL} / \mathrm{O}$ and $\mathrm{FO} / \mathrm{ER} / \mathrm{O}$ groups $(49 \%, 73 \%$ and $84 \%$, respectively) compared with the CO/AL/O group. GSSG levels showed a significant increase with age, but levels were significantly reduced in the $\mathrm{CO} / \mathrm{ER} / \mathrm{O}, \mathrm{FO} / \mathrm{AL} / \mathrm{O}$ and $\mathrm{FO} / \mathrm{ER} / \mathrm{O}$ groups $(10 \%, 15 \%$ and $13 \%$, respectively) compared with the $\mathrm{CO} / \mathrm{AL} / \mathrm{O}$ group.

Fig. 2(C) shows data on the GSH:GSSG ratio, which decreases significantly with age, indicating increased oxidative status during ageing. However, the reduction of the ratio was effectively blunted in the $\mathrm{CO} / \mathrm{ER} / \mathrm{O}, \mathrm{FO} / \mathrm{AL} / \mathrm{O}$ and $\mathrm{FO} / \mathrm{ER} / \mathrm{O}$ groups $(69 \%$, $108 \%$ and $115 \%$, respectively) compared with the CO/AL/O group. Thus, the present data clearly show that GSH level and GSH:GSSG ratio during ageing were well maintained by ER and FO supplementation.

\section{Superoxide dismutase activity}

The changes in superoxide dismutase activity are illustrated in Fig. 3(A). Decreased superoxide dismutase activity markedly increased in the $\mathrm{CO} / \mathrm{ER} / \mathrm{O}, \mathrm{FO} / \mathrm{AL} / \mathrm{O}$ and $\mathrm{FO} / \mathrm{ER} / \mathrm{O}$ groups $(63 \%, 125 \%$ and $132 \%$, respectively) compared with the $\mathrm{CO} /$ AL/O group.

\section{Catalase activity}

The effects of dietary intervention on changes in catalase activity are shown in Fig. 3(B). Similar to superoxide dismutase activity, catalase activity decreases during ageing, but levels were significantly increased in the $\mathrm{FO} / \mathrm{ER} / \mathrm{Y}, \mathrm{CO} / \mathrm{ER} / \mathrm{O}, \mathrm{FO} / \mathrm{AL} / \mathrm{O}$ and $\mathrm{FO} /$ ER/O groups $(81 \%, 15 \%, 126 \%$ and $106 \%$, respectively) compared with the CO/AL/Y and CO/AL/O groups.

\section{Glutathione peroxidase activity}

The changes in glutathione peroxidase activity are shown in Fig. 4(A). Glutathione peroxidase activity showed a slight but significant reduction with age, whereas its activity significantly increased in the $\mathrm{CO} / \mathrm{ER} / \mathrm{Y}$ and $\mathrm{FO} / \mathrm{AL} / \mathrm{Y}$ groups $(30 \%$ and $31 \%$, 

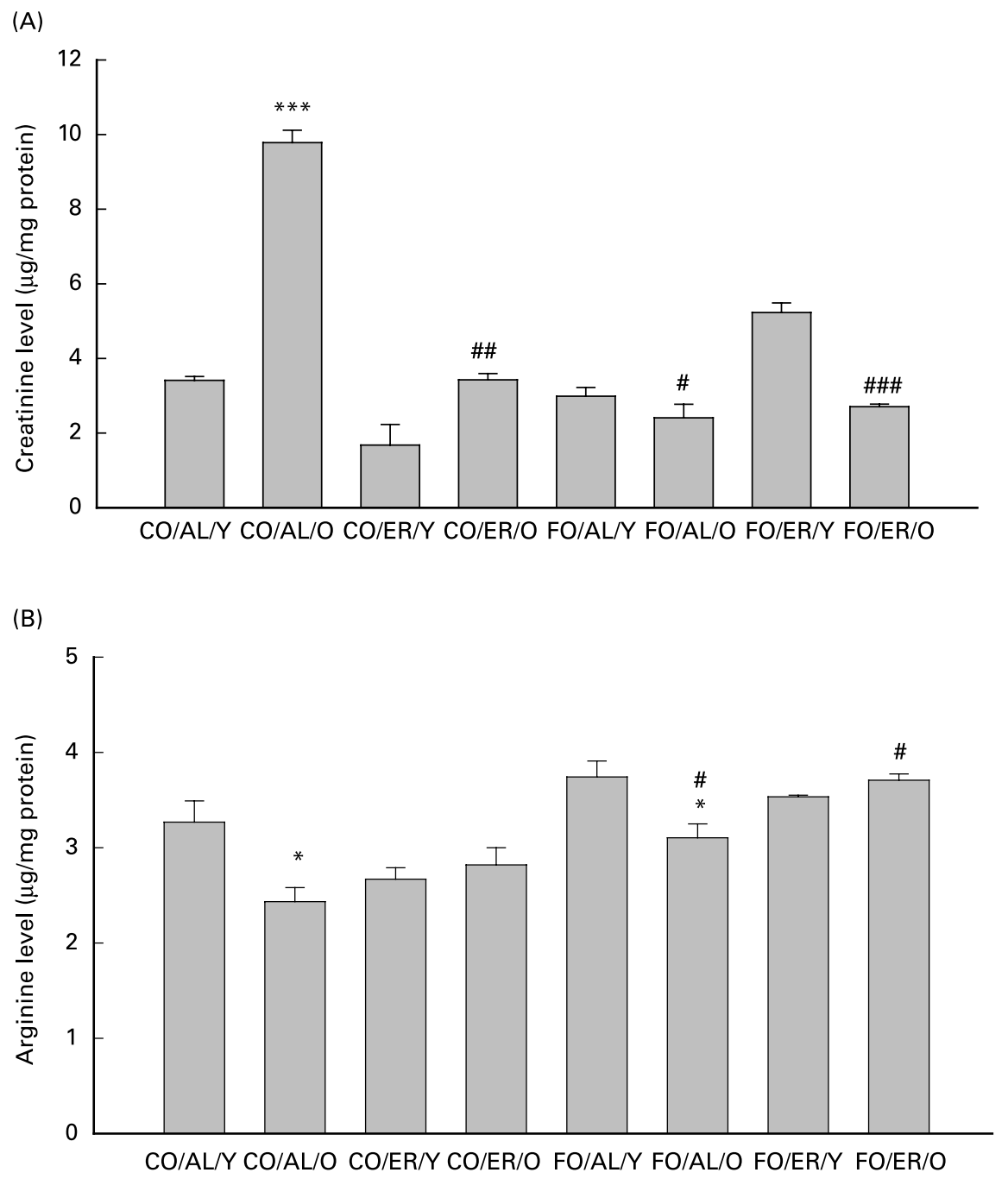

(C)

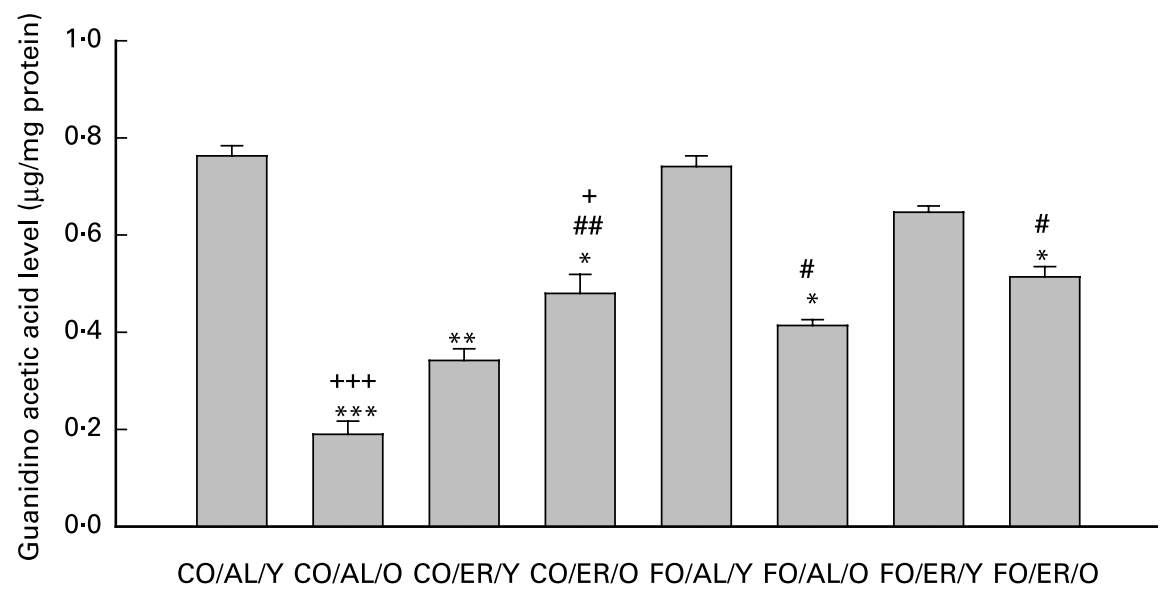

Fig. 1. Effect of energy restriction (ER) and fish oil (FO) on renal guanidino levels. (A) Effect of ER and FO on renal creatinine level (mean \pm SEM). ${ }^{* * *} P<0.001 \mathrm{~V}$. CO/AL/Y, ${ }^{\#} P<0.05$ v. CO/AL/O, ${ }^{\# \# P<0.01 ~ v . ~ C O / A L / O, ~}{ }^{\# \# \# P<0.001 ~ v . ~ C O / A L / O) . ~(B) ~ E f f e c t ~ o f ~ E R ~ a n d ~ F O ~ o n ~ r e n a l ~ a r g i n i n e ~ l e v e l ~(m e a n ~} \pm$ SEM). ${ }^{*} P<0.05 \mathrm{v}$. $\mathrm{CO} / \mathrm{AL} / \mathrm{Y},{ }^{*} P<0.05 v$ v. CO/AL/O. (C) Effect of $\mathrm{ER}$ and $\mathrm{FO}$ on renal guanidino acetic acid level (mean \pm SEM). ${ }^{*} P<0.05 v . \mathrm{CO} / \mathrm{AL} / \mathrm{Y},{ }^{* *} P<0.01 \mathrm{v} . \mathrm{CO} / \mathrm{AL} / \mathrm{Y}$, ${ }^{* * \star} P<0.001 \mathrm{v} . \mathrm{CO} / \mathrm{AL} / \mathrm{Y},{ }^{\#} P<0.05 \mathrm{v}$. CO/AL/O, ${ }^{\# \#} P<0.01 \mathrm{v} . \mathrm{CO} / \mathrm{AL} / \mathrm{O},{ }^{+++} P<0.001 \mathrm{v} . \mathrm{CO} / \mathrm{ER} / \mathrm{Y}$. CO/AL/Y, young mice fed corn oil ad libitum; CO/AL/O, old mice fed corn oil ad libitum; CO/ER/Y, young mice fed corn oil and energy-restricted; CO/ER/O, old mice fed corn oil and energy-restricted; FO/AL/Y, young mice fed fish oil ad libitum; FO/AL/O, old mice fed fish oil ad libitum; FO/ER/Y, young mice fed fish oil and energy-restricted; FO/ER/O, old mice fed fish oil and energyrestricted. 

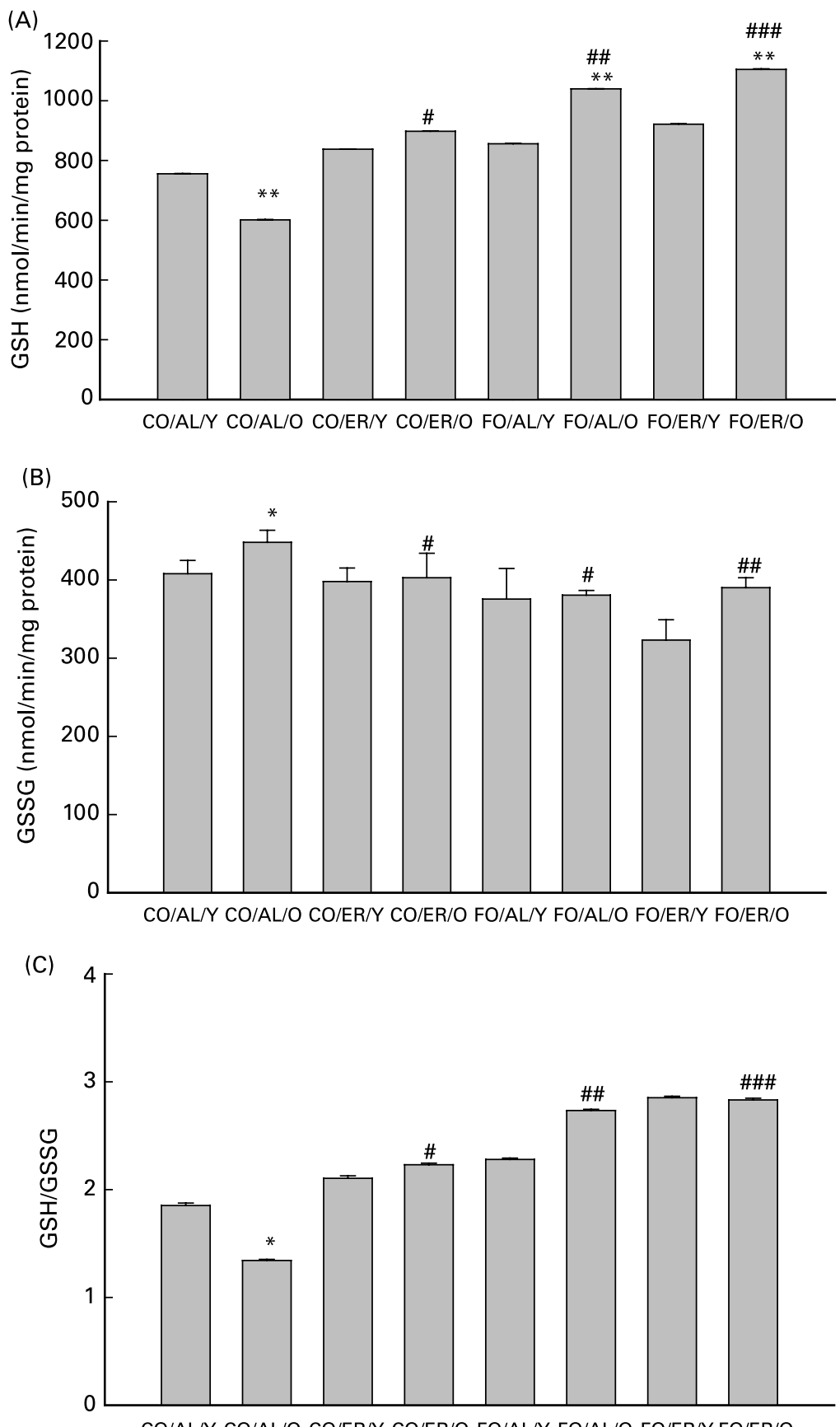

CO/AL/Y CO/AL/O CO/ER/Y CO/ER/O FO/AL/Y FO/AL/O FO/ER/Y FO/ER/O

Fig. 2. Effect of energy restriction (ER) and fish oil (FO) on oxidative stress markers. (A) Effect of ER and FO on GSH levels (mean \pm SEM). ${ }^{\star \star} P<0.01 \quad v$. $\mathrm{CO} / \mathrm{AL} / \mathrm{Y},{ }^{\#} P<0.05$ v. CO/AL/O, ${ }^{\# \#} P<0.01 \mathrm{v}$. CO/AL/O, \#\#\# $P<0.001$ v. CO/AL/O. (B) Effect of ER and FO on GSSG level (mean $\pm \mathrm{SEM}$ ). ${ }^{\star} P<0.05 \mathrm{v} . \mathrm{CO} / \mathrm{AL} / \mathrm{Y}$, ${ }^{\#} P<0.05$ v. CO/AL/O, ${ }^{\# \#} P<0.01$ v. CO/AL/O. (C) Effect of ER and FO on the GSH/GSSG ratio (mean \pm SEM). ${ }^{*} P<0.05 v$. CO/AL/Y, ${ }^{\#} P<0.05 v$. CO/AL/O, ${ }^{\#} P<0.01$ v. CO/AL/O, ${ }^{\# \#} P<0.001$ v. CO/AL/O. CO/AL/Y, young mice fed corn oil ad libitum; CO/AL/O, old mice fed corn oil ad libitum; CO/ER/Y, young mice fed corn oil and energy-restricted; CO/ER/O, old mice fed corn oil and energy-restricted; FO/AL/Y, young mice fed fish oil ad libitum; FO/AL/O, old mice fed fish oil ad libitum; FO/ER/Y, young mice fed fish oil and energy-restricted; FO/ER/O, old mice fed fish oil and energy-restricted.

respectively) compared with the $\mathrm{CO} / \mathrm{AL} / \mathrm{Y}$ group, and markedly increased in the $\mathrm{FO} / \mathrm{AL} / \mathrm{O}$ group compared with the $\mathrm{CO} / \mathrm{AL} / \mathrm{O}$ group.

\section{Glutathione reductase activity}

Glutathione reductase activity is shown in Fig. 4(B). Glutathione reductase activity showed a moderate decrease with age, but this activity significantly increased in the $\mathrm{CO} / \mathrm{ER} / \mathrm{O}, \mathrm{FO} / \mathrm{AL} / \mathrm{Y}, \mathrm{FO} /$ $\mathrm{AL} / \mathrm{O}$ and $\mathrm{FO} / \mathrm{ER} / \mathrm{O}$ groups $(28 \%, 18 \%, 42 \%$ and $38 \%$, respectively) compared with the $\mathrm{CO} / \mathrm{AL} / \mathrm{Y}$ and $\mathrm{CO} / \mathrm{AL} / \mathrm{O}$ groups.

\section{Glutathione-S-transferase activity}

The results of glutathione- $S$-transferase activities are shown in Fig. 4(C). The level of glutathione-S-transferase activity showed 
a slight reduction with age, whereas the level was significantly increased in the $\mathrm{FO} / \mathrm{ER} / \mathrm{Y}, \mathrm{FO} / \mathrm{ER} / \mathrm{O}$ and $\mathrm{CO} / \mathrm{ER} / \mathrm{O}$ groups compared with the CO/AL/Y and CO/AL/O groups. Thus, glutathione- $S$-transferase activity showed a slight reduction with age, but ER and FO moderately and significantly increased the activity.

\section{Effects of age, ER and $F O$ on reactive oxygen species generation}

The amounts of total ROS and cyclooxygenase-derived ROS are shown in Fig. 5. Total ROS generation increased with age by $20 \%$ in mice fed maize oil ad libitum, whereas it significantly decreased in the $\mathrm{CO} / \mathrm{ER} / \mathrm{O}, \mathrm{FO} / \mathrm{AL} / \mathrm{Y}, \mathrm{FO} / \mathrm{AL} / \mathrm{O}$ and FO/ER/O groups (by $36 \%, 57 \%, 81 \%$ and $94 \%$ ) compared with the $\mathrm{CO} /$ $\mathrm{AL} / \mathrm{Y}$ and $\mathrm{CO} / \mathrm{AL} / \mathrm{O}$ groups.

Maize oil-fed mice showed a marked increase of cyclooxygenase-derived ROS generation during ageing, whereas ER and FO reduced this generation in the $\mathrm{CO} / \mathrm{ER} / \mathrm{O}, \mathrm{FO} / \mathrm{AL} / \mathrm{Y}, \mathrm{FO} / \mathrm{AL} / \mathrm{O}$ and $\mathrm{FO} / \mathrm{ER} / \mathrm{O}$ groups $(92 \%, 64 \%, 93 \%$ and $97 \%$, respectively) compared with the $\mathrm{CO} / \mathrm{AL} / \mathrm{Y}$ and $\mathrm{CO} / \mathrm{AL} / \mathrm{O}$ groups. Thus, as shown in Fig. 5, total and cyclooxygenase-derived ROS generation exhibited age-related increases, whereas ER and FO effectively reduced their generation.

\section{Discussion}

$(\mathrm{NZB} \times \mathrm{NZW}) \mathrm{F}_{1}(\mathrm{~B} / \mathrm{W})$ mice are shown to have similar characteristics to the human lupus phenotype, including conditions of proteinuria, autoantibody production (especially anti-doublestranded DNA antibody) and glomerulonephritis (Okudaira et al. 1984).

Epidemiological studies have shown that an intake of longchain polyunsaturated $n-3$ fatty acids, which are abundant in FO, have beneficial effects on many human disorders and diseases, such as CVD and cancer (Hu et al. 2003; Astorg, 2004). Furthermore, it has been proved that the $n-3$ fatty acids can improve the prognosis of several chronic inflammatory diseases (Calder, 1997). Our reason why $n-3$ PUFA exhibit anti-inflammatory properties is the presence of EPA as opposed to that of eicosanoids derived from arachidonic acid. The beneficial effects of FO probably stem from the modulation of oxidative damage by $n-3$ fatty acids and the suppressive effects of FO on the ubiquitous
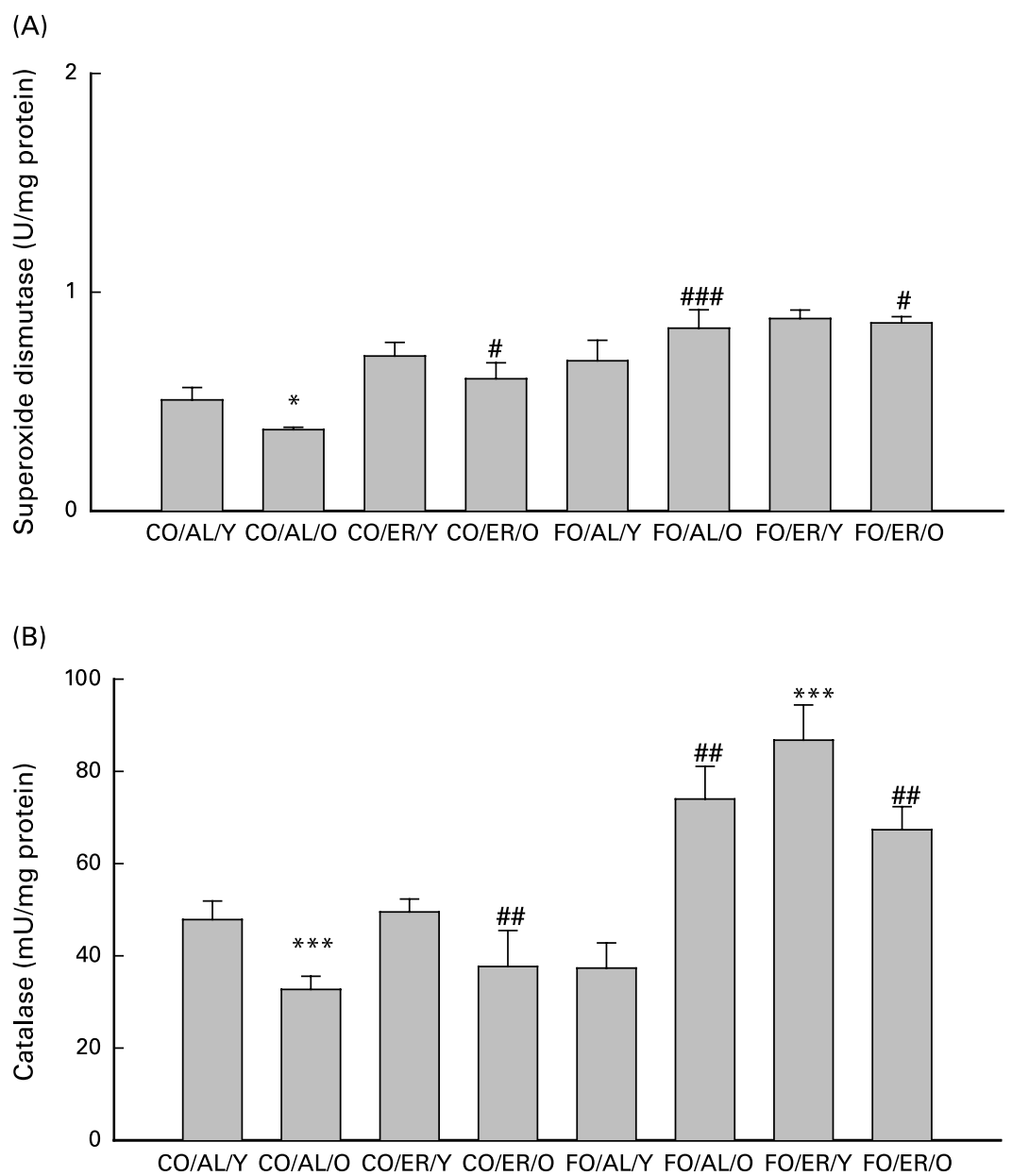

Fig. 3. Effect of energy restriction (ER) and fish oil (FO) on antioxidant enzyme activities. (A) Effect of ER and FO on superoxide dismutase activity (mean \pm SEM). ${ }^{*} P<0.05$ v. CO/AL/Y, ${ }^{\#} P<0.05$ v. CO/AL/O, ${ }^{\# \# \# P<0.001 ~ v . ~ C O / A L / O) . ~(B) ~ E f f e c t ~ o f ~ E R ~ a n d ~ F O ~ o n ~ c a t a l a s e ~ a c t i v i t y ~(m e a n ~} \pm \mathrm{SEM}$ ). ${ }^{* \star *} P<0.001$ v. CO/AL/Y, ${ }^{\#} P<0.01$ v. CO/AL/O. CO/AL/Y, young mice fed corn oil ad libitum; CO/AL/O, old mice fed corn oil ad libitum; CO/ER/Y, young mice fed corn oil and energyrestricted; CO/ER/O, old mice fed corn oil and energy-restricted; FO/AL/Y, young mice fed fish oil ad libitum; FO/AL/O, old mice fed fish oil ad libitum; FO/ER/Y, young mice fed fish oil and energy-restricted; FO/ER/O, old mice fed fish oil and energy-restricted. 
(A)

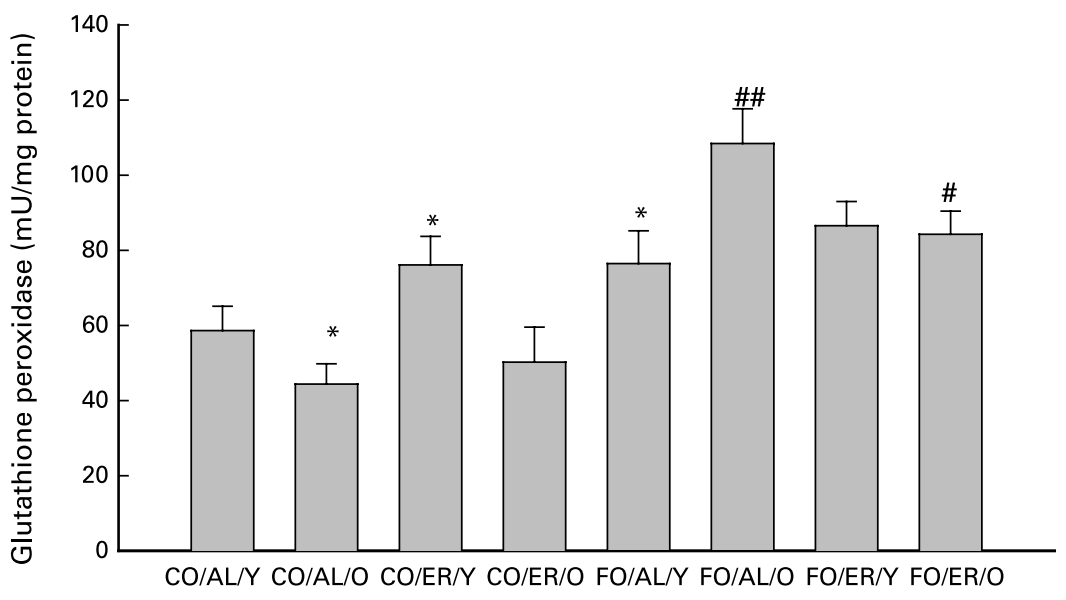

(B)

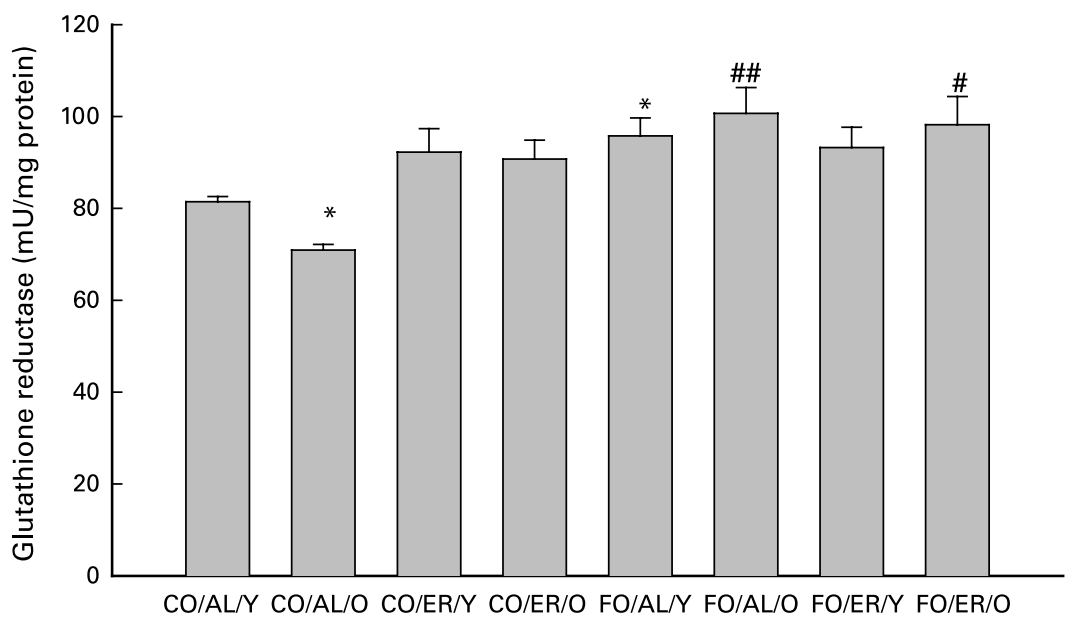

(C)

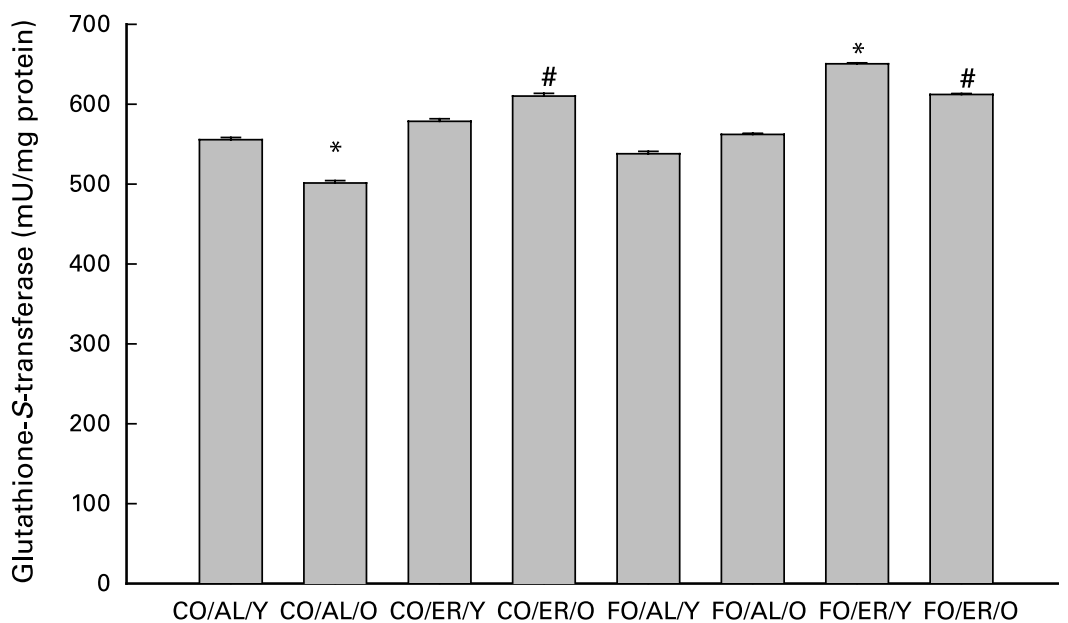

Fig. 4. Effect of energy restriction (ER) and fish oil $(F O)$ on antioxidant enzyme activities. (A) Effect of ER and FO on glutathione peroxidase activity (mean \pm SEM). ${ }^{*} P<0.05 \mathrm{v} . \mathrm{CO} / \mathrm{AL} / \mathrm{Y},{ }^{*} P<0.01 \mathrm{v} . \mathrm{CO} / \mathrm{AL} / \mathrm{Y},{ }^{*} P<0.05 \mathrm{v}$. CO/AL/O, ${ }^{*} P<0.01 \mathrm{v}$. CO/AL/O. (B) Effect of $\mathrm{ER}$ and $\mathrm{FO}$ on glutathione reductase activity (mean \pm SEM). ${ }^{*} P<0.05 \mathrm{v}$. CO/AL/Y, ${ }^{\#} P<0.05 \mathrm{v}$. CO/AL/O, ${ }^{\# \#} P<0.01 \mathrm{v}$. CO/AL/O. (C) Effect of ER and FO on glutathione-S-transferase activity (mean \pm SEM). ${ }^{*} P<0.05 \mathrm{v}$. CO/AL/Y, ${ }^{*} P<0.05 \mathrm{v}$. CO/AL/O. CO/AL/Y, young mice fed corn oil ad libitum; CO/AL/O, old mice fed corn oil ad libitum; CO/ER/Y, young mice fed corn oil and energy-restricted; CO/ER/O, old mice fed corn oil and energy-restricted; FO/AL/Y, young mice fed fish oil ad libitum; FO/AL/O, old mice fed fish oil ad libitum; FO/ER/Y, young mice fed fish oil and energy-restricted; FO/ER/O, old mice fed fish oil and energy-restricted. 
(A)

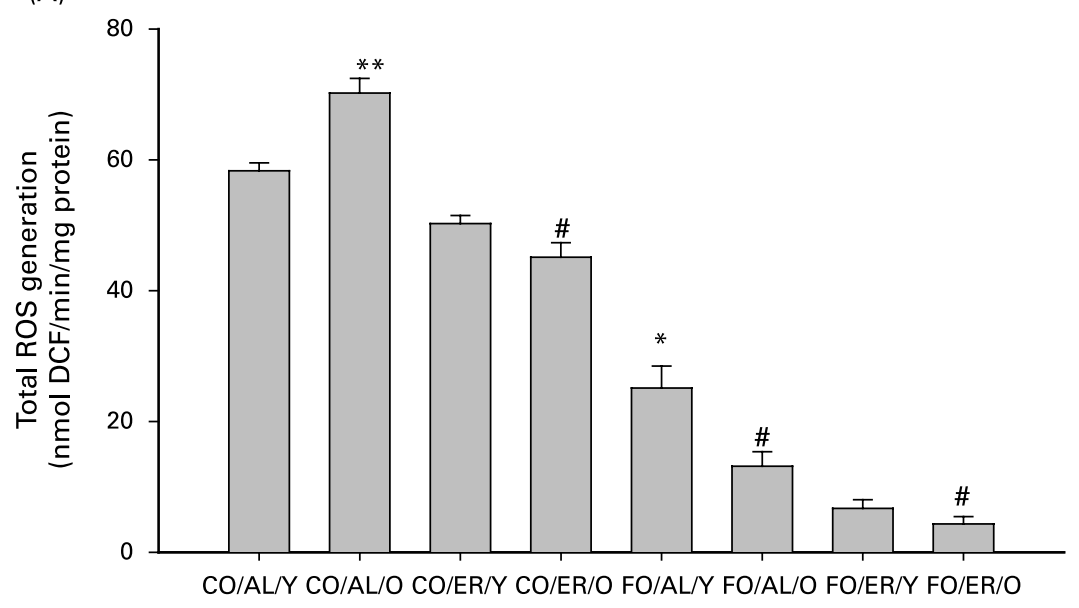

(B)

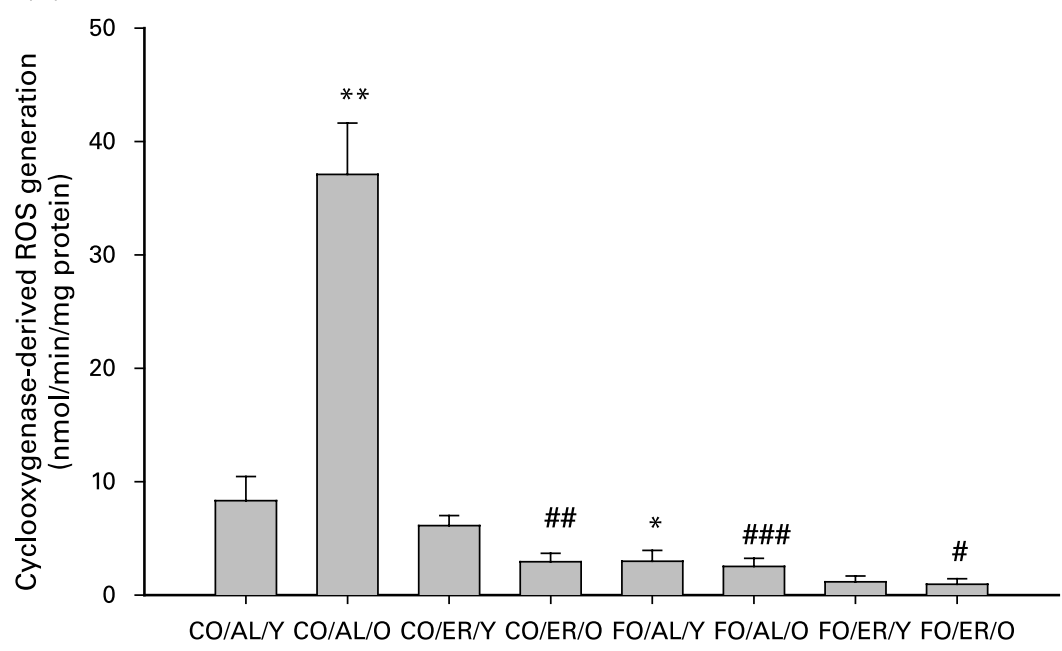

Fig. 5. Modulation of the generation of reactive oxygen species (ROS) by age, fish oil (FO) and energy restriction (ER). (A) Effect of age, FO and ER on total ROS generation (mean \pm SEM). ${ }^{*} P<0.05 \mathrm{v}$. CO/AL/Y, ${ }^{*} P<0.01 \mathrm{v}$. CO/AL/Y, ${ }^{\#} P<0.05 \mathrm{v}$. CO/AL/O). (B) Effect of age, FO and ER on cyclooxgyenase-derived ROS generation (mean \pm SEM). ${ }^{*} P<0.05 \mathrm{v}$. CO/AL/Y, ${ }^{* *} P<0.01 \mathrm{v}$. CO/AL/Y, ${ }^{\# \#} P<0.01 \mathrm{v}$. CO/AL/O, ${ }^{\# \# \# P} P<0.001 \mathrm{v}$. CO/AL/O). CO/AL/Y, young mice fed corn oil ad libitum; CO/AL/O, old mice fed corn oil ad libitum; CO/ER/Y, young mice fed corn oil and energy-restricted; CO/ER/O, old mice fed corn oil and energyrestricted; FO/AL/Y, young mice fed fish oil ad libitum; FO/AL/O, old mice fed fish oil ad libitum; FO/ER/Y, young mice fed fish oil and energy-restricted; FO/ER/O, old mice fed fish oil and energy-restricted.

pro-inflammatory, redox-sensitive NF- $\mathrm{B}$ transcription factor, and the concomitant activation of PPAR- $\alpha$ (Sethi, 2002).

Nutrients rich in anti-inflammatory $n-3$ fatty acids, as in FO, have the potential to abrogate lupus nephritis, which is known to be involved in the pathogenesis of vascular damage (Clark \& Parbtani, 1994). Also, FO combined with antioxidants is shown to extend the lifespan of lupus-prone $(\mathrm{NZB} \times \mathrm{NZW}) \mathrm{F}_{1}(\mathrm{~B} / \mathrm{W})$ female mice (Fernandes et al. 1996). In addition, ER and FO are shown to suppress atherogenic risk factors in lupus-prone $(\mathrm{NZB} \times \mathrm{NZW}) \mathrm{F}_{1}$ mice (Muthukumar et al. 2003); furthermore, $\mathrm{ER}$ and $\mathrm{FO}$ have been shown to reduce inflammation and disease severity in lupus nephritic animal models (Fernandes, 1994). However, the protective mechanisms at the molecular level underlying these effects have not been clearly delineated.

Although it is known that ER and FO diminish histological evidence of glomerulonephritis in lupus-prone $(\mathrm{NZB} \times \mathrm{NZW})$ $\mathrm{F}_{1}$ (B/W) mice (Troyer et al. 1997), their efficacy on the modulation of GUC has not been reported. In the present work, we report for the first time on GUC levels in relation to oxidative stress and antioxidant defences in $\mathrm{B} / \mathrm{W}$ mice. GC, intermediates of arginine metabolism, change under various pathological conditions, particularly when urea cycle and renal insufficiencies occur (Levillain et al. 2001). In this present work, creatinine showed age-related increases, and arginine and guanidino acetic acid showed age-dependent declines, which correlated with the other data showing that kidney function and morphology gradually deteriorate with age (Baylis \& Schmidt, 1996). Our results showed that renal arginine decreased with age, this fall being effectively blunted by ER and FO in both young and old mice.

In conditions of chronic renal insufficiency, serum levels of guanidino acetic acid are reported to be significantly decreased (Shainkin et al. 1975). As shown in Fig. 1(C) earlier, we observed a similar decrease in renal guanidino acetic acid, but this decrease was reversed by ER and FO feeding. In addition, the marked 
increase in creatinine with age that we expected in this strain of mice was effectively ameliorated by both dietary interventions. It is interesting to note that short-term feeding (less than 3 months) exerts beneficial effects even in young mice (Fig. 1(A)), indicating the high efficacy of ER and FO on renal function. The increase of creatinine with age might arise from an age-related increase in muscle catabolism and/or altered age-related renal creatinine clearance related to renal function and the nephropathic condition. Our findings on the lowering of creatinine level by ER or FO are further indications that ER and FO do have beneficial effects on renal insufficiency, improving renal function in old mice.

Glomerular injury is aggravated by increased free radicals (Patel et al. 2003). Oxidative stress has been suggested for the progression of chronic renal insufficiency by inflicting glomerular and tubular damage (Satoh et al. 2003).

The molecular mechanism underlying these deleterious glomerular changes may be related to the activation of the pro-inflammatory NF- $\kappa B$ by oxidative stress. Our laboratory recently reported that the activation of NF- $\mathrm{BB}$ plays a pivotal role in the inflammatory process, as shown in the kidney during ageing (Kim et al. 2002). The activation of NF- $\kappa$ B by uraemic toxin and the upregulation of plasminogen activator inhibitor-1 in tubular cells provided further support for this suggested molecular mechanism (Motojima et al. 2003).

Our current data on the positive effects of ER and FO feeding are consistent with an earlier report showing the beneficial effect of ER on the reduction of lipid peroxidation and the effects of FO on the attenuation of kidney disease in NZB/NZW mice (Chandrasekar \& Fernandes, 1994; Jolly et al. 2001).

However, our current study obtained new oxidative stress-related data on these mice that had not previously been reported. For example, the assessment of oxidative status by measuring the GSH:GSSG ratio, which is a better overall marker of oxidative stress, total ROS and cyclooxgyenase-derived ROS, as well as the activity of scavenging enzymes such as glutathione reductase, have not been included in others' reports (Jolly et al. 2001a,b). In addition, the increased glutathione peroxidase and glutathione- $S$ transferase activities we report in the present study were more discernable than those reported by Jolly et al. In their study, glutathione peroxidase activity was not affected by age but was increased by $30 \%$ with ER or FO, whereas glutathione-S-transferase was not affected by age or dietary intervention (Jolly et al. 2001a,b).

Putting these findings together, we propose that the suppression of oxidative stress by reducing ROS production and enhancing the antioxidant defence system, and the modulation of GUC by ER and $\mathrm{FO}$ feeding in lupus-prone $(\mathrm{NZB} \times \mathrm{NZW}) \mathrm{F}_{1} \mathrm{~B} / \mathrm{W}$ mice, are the likely mechanism underlying the amelioration of renal damage. This conclusion was also supported by our present data on the suppression of cyclooxygenase-derived ROS generation and other oxidative markers, which strongly indicate that ER and FO protected the animals against renal insufficiency and damage by modulating the pro-inflammatory status of these mice. Our data provide evidence of a plausible mechanism through which the suppression of oxidative stress can provide protective effects against auto-immune-related renal dysfunction during ageing.

\section{Acknowledgements}

This work was supported by a grant from Pusan National University. The authors are grateful to Dr Gabriel Fernandes for providing tissue, and our appreciation goes to Dr Byung $\mathrm{Pal} \mathrm{Yu}$ for his help in preparing this manuscript.

\section{References}

Aebi H (1984) Catalase in vitro. Methods Enzymol 105, 121-126.

Ali SF, LeBel CP \& Bondy SC (1992) Reactive oxygen species formation as a biomarker of methylmercury and trimethyltin neurotoxicity. $\mathrm{Neu}$ rotoxicology $13,637-648$.

Astorg P (2004) Dietary N-6 and N-3 polyunsaturated fatty acids and prostate cancer risk: a review of epidemiological and experimental evidence. Cancer Causes Control 15, 367-386.

Baylis C \& Schmidt R (1996) The aging glomerulus. Semin Nephrol 16, 265-276.

Calder PC (1997) n-3 polyunsaturated fatty acids and cytokine production in health and disease. Ann Nutr Metab 41, 203-234.

Cardinali DP, Garcia AP, Cano P \& Esquifino AI (2004) Melatonin role in experimental arthritis. Curr Drug Targets Immune Endocr Metabol Disord 4, 1-10.

Chandrasekar B \& Fernandes G (1994) Decreased pro-inflammatory cytokines and increased antioxidant enzyme gene expression by omega-3 lipids in murine lupus nephritis. Biochem Biophys Res Commun 200, 893-898.

Chung HY, Kim HJ, Kim KW, Choi JS \& Yu BP (2002) Molecular inflammation hypothesis of aging based on the anti-aging mechanism of calorie restriction. Microsc Res Tech 59, 264-272.

Chung HY, Kim HJ, Kim JW \& Yu BP (2001) The inflammation hypothesis of aging: molecular modulation by calorie restriction. Ann NY Acad Sci 928, 327-335.

Clark WF \& Parbtani A (1994) Omega-3 fatty acid supplementation in clinical and experimental lupus nephritis. Am J Kidney Dis 23, 644-647.

Fernandes G (1994) Dietary lipids and risk of autoimmune disease. Clin Immunol Immunopathol 72, 193-197.

Fernandes G, Chandrasekar B, Luan X \& Troyer DA (1996) Modulation of antioxidant enzymes and programmed cell death by n-3 fatty acids. Lipids 31, S91-S96.

Guarnieri G, Antonione R \& Biolo G (2003) Mechanisms of malnutrition in uremia. J Ren Nutr 13, 153-157.

Habig WH, Pabst MJ \& Jakoby WB (1974) Glutathione S-transferases. The first enzymatic step in mercapturic acid formation. J Biol Chem 249, 7130-7139.

Higashidate S, Maekubo T, Saito M, Senda M \& Hoshino T (1984) Rapid and highly sensitive method for the determination of guanidino compounds in body fluids. Bunseki kagaku 33, 366-370.

Hu FB, Cho E, Rexrode KM, Albert CM \& Manson JE (2003) Fish and long-chain omega-3 fatty acid intake and risk of coronary heart disease and total mortality in diabetic women. Circulation 107, 1852-1857, Epub 2003 Mar 31.

Jolly CA, Muthukumar A, Avula CP, Troyer D \& Fernandes G (2001a) Life span is prolonged in food-restricted autoimmune-prone (NZB $\times$ NZW)F(1) mice fed a diet enriched with (n-3) fatty acids. $J$ Nutr 131, 2753-2760.

Jolly CA, Muthukumar A, Reddy Avula CP \& Fernandes G (2001b) Maintenance of NF-kappaB activation in T-lymphocytes and a naive T-cell population in autoimmune-prone (NZB/NZW)F(1) mice by feeding a food-restricted diet enriched with n-3 fatty acids. Cell Immunol $\mathbf{2 1 3}$, $122-133$.

Judex S, Wohl GR, Wolff RB, Leng W, Gillis AM \& Zernicke RF (2000) Dietary fish oil supplementation adversely affects cortical bone morphology and biomechanics in growing rabbits. Calcif Tissue Int 66, 443-448.

Kim HJ, Jung KJ, Yu BP, Cho CG, Choi JS \& Chung HY (2002) Modulation of redox-sensitive transcription factors by calorie restriction during aging. Mech Ageing Dev 123, 1589-1595.

Kono DH \& Theofilopoulos AN (2000) Genetics of systemic autoimmunity in mouse models of lupus. Int Rev Immunol 19, 367-387. 
Kubo C, Johnson BC, Day NK \& Good RA (1984) Calorie source, calorie restriction, immunity and aging of (NZB/NZW)F1 Mice. J Nutr 114, 1884-1899.

Levillain O, Marescau B, Possemiers I, Al Banchaabouchi M \& De Deyn PP (2001) Influence of $72 \%$ injury in one kidney on several organs involved in guanidino compound metabolism: a time course study. Pflugers Arch 442, 558-569.

Lowry OH, Rosebrough NJ \& Farr AL (1951) Protein measurement with the Folin phenol reagent. J Biol Chem 193, 265-275.

McCord JM \& Fridovich I (1988) Superoxide dismutase: the first twenty years (1968-1988). Free Radic Biol Med 5, 363-369.

Morrow WJ, Ohashi Y, Hall J, Pribnow J, Hirose S, Shirai T \& Levy JA (1985) Dietary fat and immune function. Antibody responses, lymphocytes and accessory cell function in (NZB/NZW)F1 mice. J Immunol 135, 3857-3863.

Motojima M, Hosokawa A, Yamato H, Muraki T \& Yoshioka T (2003) Uremic toxins of organic anions up-regulate PAI-1 expression by induction of NF-kappaB and free radical in proximal tubular cells. Kidney Int 63, 1671-1680.

Muthukumar AR, Jolly CA, Zaman K \& Fernandes G (2000) Calorie restriction decreases proinflammatory cytokines and polymeric $\mathrm{Ig}$ receptor expression in the submandibular glands of autoimmune prone $(\mathrm{NZB} \times \mathrm{NZW}) \mathrm{F} 1$ mice. J Clin Immunol 20, 354-361.

Muthukumar A, Zaman K, Lawrence R, Barnes JL \& Fernandes G (2003) Food restriction and fish oil suppress atherogenic risk factors in lupusprone $(\mathrm{NZB} \times \mathrm{NZW}) \mathrm{F} 1$ mice. $J$ Clin Immunol 23, 23-33.

Nohara Y, Usui T, Kinoshita T \& Watanabe M (2002) Generation of superoxide anions during the reaction of guanidino compounds with methylglyoxal. Chem Pharm Bull 50, 179-184.

Okudaira H, Terada E, Fukuda K, Ito T, Gohda A, Nomura T, Kudo K, Ogita T \& Miyamoto T (1984) Treatment of NZB/W F1 mice with NZW splenic $\mathrm{T}$ cells or with serum of mice experiencing the graftversus-host reaction: suppression of ongoing anti-double-stranded (ds) DNA antibody formation and improvement of renal function. Clin Immunol Immunopathol 32, 359-367.
Pandey A \& Katiyar SS (1996) Inactivation of yeast glutathione reductase by O-phthalaldehyde. J Enzyme Inhib 11, 141-149.

Patel J, Manjappa N, Bhat R, Mehrotra P, Bhaskaran M \& Singhal PC (2003) Role of oxidative stress and heme oxygenase activity in morphine-induced glomerular epithelial cell growth. Am J Physiol Renal Physiol 285, F861-F869.

Pey A, Saborido A, Blazquez I, Delgado J \& Megias A (2003) Effects of prolonged stanozolol treatment on antioxidant enzyme activities, oxidative stress markers, and heat shock protein HSP72 levels in rat liver. J Steroid Biochem Mol Biol 87, 269-277.

Reddy Avula CP, Lawrence RA, Zaman K \& Fernandes G (2002) Inhibition of intracellular peroxides and apoptosis of lymphocytes in lupus-prone B/W mice by dietary n- 6 and n-3 lipids with calorie restriction. J Clin Immunol 22, 206-219.

Sailaja YR, Baskar R \& Saralakumari D (2003) The antioxidant status during maturation of reticulocytes to erythrocytes in type 2 diabetics. Free Radic Biol Med 35, 133-139.

Satoh M, Hayashi H, Watanabe M, Ueda K, Yamato H, Yoshioka T \& Motojima M (2003) Uremic toxins overload accelerates renal damage in a rat model of chronic renal failure. Nephron Exp Nephrol 95, e111-e118.

Sethi S (2002) Inhibition of leukocyte-endothelial interactions by oxidized omega-3 fatty acids: a novel mechanism for the anti-inflammatory effects of omega-3 fatty acids in fish oil. Redox Rep 7, 369-378.

Shainkin R, Berkenstadt Y, Giat Y \& Berlyne GM (1975) An automated technique for the analysis of plasma guanidino acids, and some findings in chronic renal disease. Clin Chim Acta 60, 45-50.

Tappel AL, Tappel AA \& Fraga CG (1989) Application of simulation modeling to lipid peroxidation processes. Free Radic Biol Med 7, 361-368.

Troyer DA, Chandrasekar B, Barnes JL \& Fernandes G (1997) Calorie restriction decreases platelet-derived growth factor (PDGF)-A and thrombin receptor mRNA expression in autoimmune murine lupus nephritis. Clin Exp Immunol 108, 58-62.

Vanholder R (2003) Uremic toxins. Nephrologie 24, 373-376. 